Scientific Journal. ISSN 2595-9433

Volume 3, Number 1, Article n. 3, January/June

D.O.I. http://dx.doi.org/10.35418/2526-4117/v3n1a3

Received: 11/06/2020 - Accepted: 12/16/2020

\title{
BIOCIDE POTENTIAL OF EXTRACTS OF Jatropha curcas L. ON FUNGI Hemileia vastatrix AND Cercospora coffeicola: CAUSAL AGENTS OF TWO MAIN DISEASES OF THE COFFEE TREES
}

\author{
Iasmine Ramos Zaidan ${ }^{1}$, (D) Luiz Antônio dos Santos Dias ${ }^{1 *}$, (D) Dandara \\ Rego Muniz ${ }^{1}$, (D) Rafael Tassinari Resende ${ }^{2}$, (D) João Paulo Viana Leite ${ }^{3}$, \\ (D) Olinto Liparini Pereira ${ }^{4}$, (D) Juliana Aparecida Diniz ${ }^{1}$ \\ 1 Departamento de Agronomia, Universidade Federal de Viçosa, 36570-900, Viçosa, MG, Brasil. \\ 2 Escola de Agronomia, Universidade Federal de Goiás, Av. Esperança s/n, Campus Samambaia, \\ 74.690-900, Goiânia, GO, Brasil. \\ 3 Departamento de Biologia Vegetal, Universidade Federal de Viçosa, 36570-900, Viçosa, MG, \\ Brasil. \\ 4 Departamento de Fitopatologia, Universidade Federal de Viçosa, 36570-900, Viçosa, MG, Brasil. \\ * Corresponding author: Luiz Antônio dos Santos Dias (lasdias@ufv.br).
}

\begin{abstract}
The toxicity of $J$. curcas opens possibilities of breeding program on the production of extracts for controlling the plant pathogens. The H. vastatrix and C. coffeicola fungi causing leaf rust and cercosporiosis diseases, and can be responsible for up to $50 \%$ and $30 \%$ coffee yield loss, respectively. We developed a biocide for controlling the both fungi, using leaf and stem bark samples from 12 families of $J$. curcas and submitted them to extraction by ethanol and chloroform solvents. In assays with $H$. vastatrix, we used $15 \mu \mathrm{L}$ of spore suspension and $15 \mu \mathrm{L}$ of the $J$. curcas extract. Assays with $C$. coffeicola were performed by using isolates from coffee leaves bearing the disease, grew in PDA medium. For each family, $15 \mathrm{~mL}$ of PDA medium and $1 \mathrm{~mL}$ of the plant extract were utilized. From the third day on, the mycelial growth was assessed every 24 hours, during 13 days, by evaluating the diameter of the colonies. Data on the antifungal effect of the extracts over $C$. coffeicola mycelia were subjected to two-way anova. The mean testing was performed as model-identity test, as there was an over-time growth. All 12 extracts of stem bark and leaves of $J$. curcas, prepared with either ethanol or chloroform, proved to be efficient in controlling $H$. vastatrix. For $C$. coffeicola, the extracts inhibited partially the mycelial growth. The extracts that had ethanol as a solvent were more toxic and this result is relevant because ethanol is more accessible to the farmers and the extraction is less expensive.
\end{abstract}

Keywords: Physic nut; green biocide; secondary metabolites; coffee rust; cercosporiosis. 


\section{Introduction}

Jatropha curcas L., popularly known as physic nut, is an oilseed plant of the family Euphorbiaceae, whose putative origin and domestication center is Mexico (Dias et al., 2012; Li et al., 2017; CAB International, 2019). The potential advantage of cultivating this species resides in its multipurpose character, as it can be used for biodiesel and biokerosene production due to the high oil content of the seeds $(38 \%$ on average). Other positive aspects include the considerable adaptability to different agroclimatic conditions, the non-competition with food crops, and the high biomass formation, which can be employed in animal feed and fertilizer manufacturing, once duly detoxified. It presents biocide characteristics that might be applied to controlling pest and diseases of crops (Pua et al., 2011; Akashi, 2012; Dias et al., 2012; Pandey et al., 2012; Abdual Khalil et al., 2013; Li et al., 2017; Muniz et al., 2019; Cavalcante et al., 2020).

The use of plants that produce secondary metabolites that have insecticide, fungicide and herbicide properties, with little to none residual effect, might replace or at least decrease the indiscriminate application of pesticides, reducing their environmental impact (Ootani et al., 2013). Among the substances with such attributes, the most prominent ones include diterpenes, sesquiterpenoids and triterpenes, alkaloids, flavonoids, phenolic compounds, lignans, neolignans, coumarins, coumarins-lignoides, phytosterols and proteins (Abdelgadir and Van Staden, 2013; Muniz et al., 2019; Cavalcante et al., 2020). The biocide potential of $J$. curcas comes from toxic and antinutritional secondary metabolites existing within all its organs. The degree of toxicity varies with the extract prepared, the nature of the testingsubstance, the dose and administration method, and the sensitivity of the individuals (Devappa et al., 2010; Muniz et al., 2019).

The coffee leaf rust, caused by the biotrophic fungus Hemileia vastatrix, is the main disease affecting the culture. It makes the plant shed its leaves prematurely, with subsequently drying of productive branches, before flowering. Once the formation of flower buds is compromised, the development of fruits decreases, therefore negatively impacting productivity. The severity of this disease is directly linked to the edaphoclimatic conditions. Depending on the altitude, climate and nutritional state of the plant, the coffee leaf rust can be responsible for up to $50 \%$ yield loss (Amorim et al., 2016; Carvalho et al., 2017). In Brazil, the most varieties are susceptible to the fungus (Silva et al., 2016; Faria et al., 2017).

Cercosporiosis is another disease that profoundly affects coffee quality. Its etiologic agent is the fungus Cercospora coffeicola, which causes leaves to fall, and fruits to mature and drop too early. This disease is widely spread and has shown a considerable aggressiveness in coffee plantations, where it accounts for up to 30\% production loss (Zambolim, 1999; Silva et al., 2015; Amorim et al., 2016). The present study aimed at developing new botanical extracts from stem bark and leaves of Jatropha curcas L. and testing them on phytopathogenic fungi that cause disease coffee trees, such as coffee leaf rust (Hemileia vastatrix) and cercosporiosis (Cercospora coffeicola).

\section{Material and methods}

Stem bark and leaf samples were collected from $12 \mathrm{~J}$. curcas's families. They had been preselected based on oil yield superiority (Cardoso et al., 2018), from a set of 121 families used in a progeny test conducted at the experimental farm (latitude $20^{\circ} 40,00.8 ” \mathrm{~S}$, longitude $42^{\circ} 31^{\prime} 05.1$ ' W, and altitude $985 \mathrm{~m}$ asl) of the Universidade Federal de Viçosa, located in the city of Araponga, state of Minas Gerais (MG), Brazil. After that, samples were weighed, stowed in paper bags, and placed inside a forced-convection oven at $50{ }^{\circ} \mathrm{C}$. They were kept in those conditions until weight stabilization. After dried, the stem barks and leaves were ground in a knife mill for 10 and 5 minutes, respectively, until the obtention of fine powders. These materials were then transferred to previously identified amber glass containers, which were kept at normal temperature.

The two following solvents were employed to prepare the botanical extracts: ethanol, for extracting apolar secondary metabolites, and chloroform, for the polar ones. Water and dimethyl sulfoxide (DMSO 2\%) were used as 
control. The preparation of extracts was made exhaustively by applying the Soxhlet method (Horwitz, 1975) in sequential way, first using chloroform as the solvent and, in sequence, ethanol $2 \%$ (water).

The stem extract was made with $40 \mathrm{~g}$ of the stem bark, $270 \mathrm{~mL}$ of chloroform, and $270 \mathrm{~mL}$ of ethanol. The leaf extract, in its turn, was prepared with $20 \mathrm{~g}$ of ground leaves, $250 \mathrm{~mL}$ of chloroform, and $250 \mathrm{~mL}$ of ethanol. By the end of this process, each sample was taken to a rotary evaporator, to remove the solvents. After that, the extracts were poured into glass containers wrapped in tinfoil and placed into an evaporation chamber, so that to eliminate the liquid phase, leaving just the solids. Overall, 48 extracts from the 12 families were tested, employing two extracting agents for two plant organs (stem bark and leaves), and two control treatments (water and DMSO 2\%). All samples were frozen at $-80{ }^{\circ} \mathrm{C}$ for $24 \mathrm{~h}$ and subsequently lyophilized until complete removal of the remaining water and solvent.

\section{Assays with Hemilea vastatrix}

A coffee seedling of the cultivar Caturra had to be inoculated for the assays with $H$. vastatrix, as the fungus does not grow in culture media. Once the spores had fully developed (approximately two months after inoculation), they were harvested and diluted in $1 \mathrm{~mL}$ of water with the reagent Tween (polysorbate 80 ). The spore concentration was quantified in a Neubauer chamber. The assays were arranged in plastic gerboxes, which had their bottom lined with some wet paper towel and equipped with plastic screens. Two glass slides were lain on every screen, each containing $15 \mu \mathrm{L}$ of spore suspension and $15 \mu \mathrm{L}$ of botanical extract from one of the 12 families studied. Overall, four repetitions were carried out per box, and two drops of the solution (spore suspension + extract) were put upon each slide. The boxes were closed, enveloped with tinfoil to emulate a dark environment, and then kept in a
BOD chamber at $22{ }^{\circ} \mathrm{C}$. Six hours afterward, the spore germination was interrupted by adding lactophenol. The solution (spore suspension + extract + lactophenol) was topped with a cover glass, and the set was observed under an Olympus CX 31 microscope. Photomicrographs were taken with the aid of an Olympus BX 53 microscope, using the objective lenses of 10x and 40x.

\section{Assays with Cercospora coffeicola}

The antifungal assays with Cercospora coffeicola were performed by using isolates from coffee leaves bearing the disease. The fungus grew in PDA (potato dextrose agar) medium, inside Petri dishes dimensioned $90 \times 15 \mathrm{~mm}$. The medium had been previously sterilized in a vertical floor-standing autoclave, model 415 $\left(\right.$ FANEM $\left.^{\circledR}\right)$, for 20 minutes; whereas the Petri dishes had been kept in a BOD chamber at $25^{\circ} \mathrm{C}$ for 13 days. For these assays, $150 \mathrm{mg}$ of stem bark extract of all the $12 \mathrm{~J}$. curcas families were weighed inside Falcon ${ }^{\circledR} 15-\mathrm{mL}$ test tubes. Three milliliters of DMSO $2 \%$ aqueous solution were added to each tube, and they were subsequently autoclaved for 20 minutes, to assure the complete destruction of microorganisms.

The testing with the fungus was conducted in triplicates for each family, using Petri dishes dimensioned $60 \times 15 \mathrm{~mm}$, which had been stowed inside a flow chamber. They were added of $15 \mathrm{~mL}$ of pre-autoclaved PDA medium and 1 $\mathrm{mL}$ of the plant extract. When the mixture solidified, a 5-mm PDA disc was placed on top of it, containing $C$. coffeicola mycelia. The dishes were wrapped in plastic film and then stored in a BOD chamber at $25^{\circ} \mathrm{C}$. From the third day on, the mycelial growth was assessed every 24 hours, for the following 13 days. The diameter of the colonies was evaluated, in two opposite directions, to evaluate its development. The data were employed to calculate the percentage of mycelial growth inhibition (PMGI), according to the following equation.

$$
P M G I=\frac{(\text { Diameter of control treatment with DMSO 2\% })-(\text { Diameter of treatment })}{\text { Diameter of control treatment with DMSO } 2 \%} \times \%
$$

The data on the antifungal effect of the extracts over $C$. coffeicola mycelia were subjected to two-way analyses of variance (anova), in a split-split plot scheme (Dias and
Barros, 2009). The mean testing was performed as model-identity test, as there was an over-time growth. These statistical analyses were performed with the software R. 


\section{Results and discussion Assays with Hemilea vastatrix}

The assays with the $12 \mathrm{~J}$. curcas families demonstrated that, for stem bark as well as for leaves, extracted with either chloroform or ethanol, the germination of uredospores of $H$. vastatrix was effectively inhibited, in compari-son with the controls (water and DMSO 2\%). This is a particularly promising outcome, as $H$. vastatrix is a biotrophic fungus, which suggests that the testing conditions can be replicated for different types of rust affecting other economically important crops, such as eucalyptus, soybean, and guava. In Figure 1, germinated $H$. vastatrix spores can be seen in the photomicrographs involving control treatments, whereas no germination is seen in the extracts.

All extracts evaluated for $H$. vastatrix proved to be efficient in controlling spore germination. A similar finding was obtained by Silva et al. (2014), who checked the effectiveness of extracts of Allium sativum and Syzygium aromaticum. Caetano et al. (2017), in their turn, tested essential oil extracts of Eucalyptus microcorys against $H$. vastatrix, and verified that, up from a 250-ppm concentration, the spore germination reduced by 79.5\%. Neem (Azadirachta indica) is another plant largely employed in alternative disease-control methods. Duarte et al. (2018) reported that the ethanolic extract of neem leaves could suppress the germination of rust spores by $43.5 \%$ (at the lowest concentration of $1 \%$ ) and by $67.78 \%$ (at the highest level of $4 \%$ ).

Wei et al. (2004) investigated the effect of curcin, another secondary metabolite of $J$. curcas, over the fungi Magnaporthe grisea, Pestalotia funerea, Rhizoctonia solani, and Sclerotinia sclerotiorum. Their results were comparable to those of the present study, regarding the limitation of spore germination and mycelial development. At the dose of $5 \mu \mathrm{g} \mathrm{mL}^{-1}$ of curcin, these factors were significantly hampered, and when the dose was increased to $50 \mu \mathrm{g} \mathrm{mL}^{-1}$, the inhibition rate of P. funerea reached $83.8 \%$.

\section{Assays with Cercospora coffeicola}

The mycelial growth during the 13-day span was more prominent in the controls (water and DMSO 2\%) than those with stem bark and leaf extracts (Figure 2).
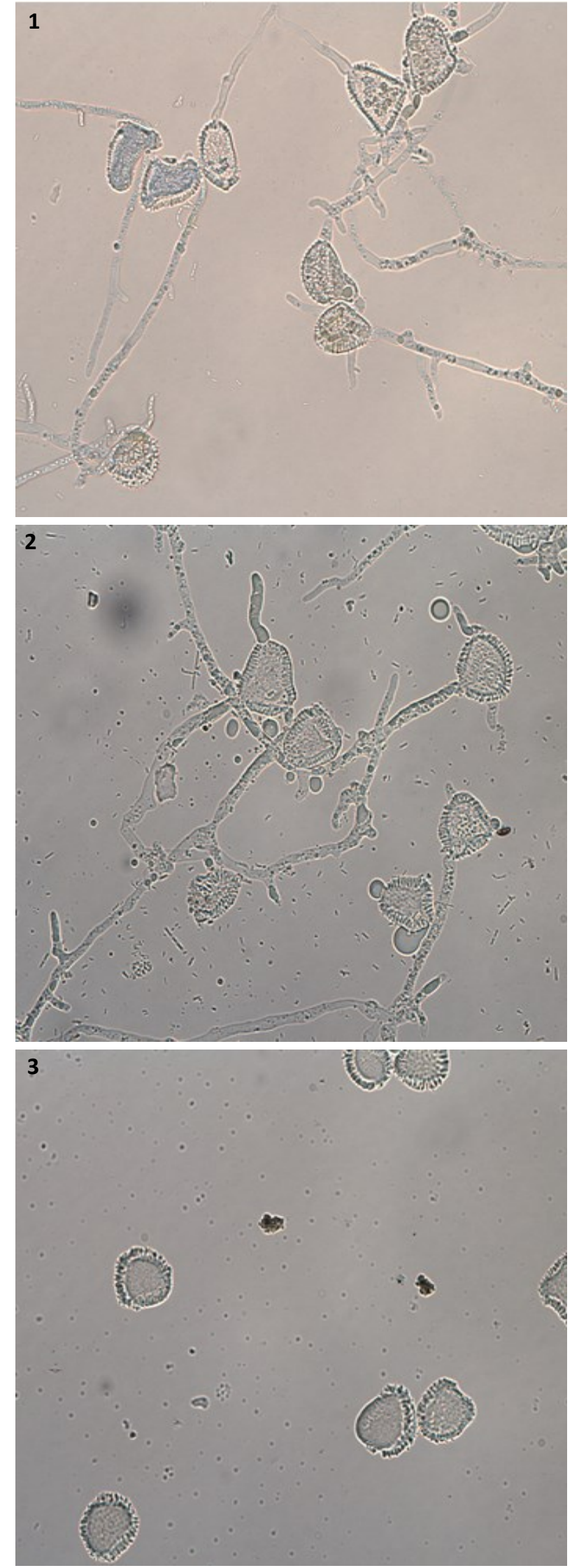

Figure 1. Photomicrographs of germinated uredospores $(20 \mu \mathrm{m})$ in the controls with water (1) and DMSO 2\% (2); and non-germination of uredospores in the stem bark and leaves of Jatropha curcas L. extracts (3). 

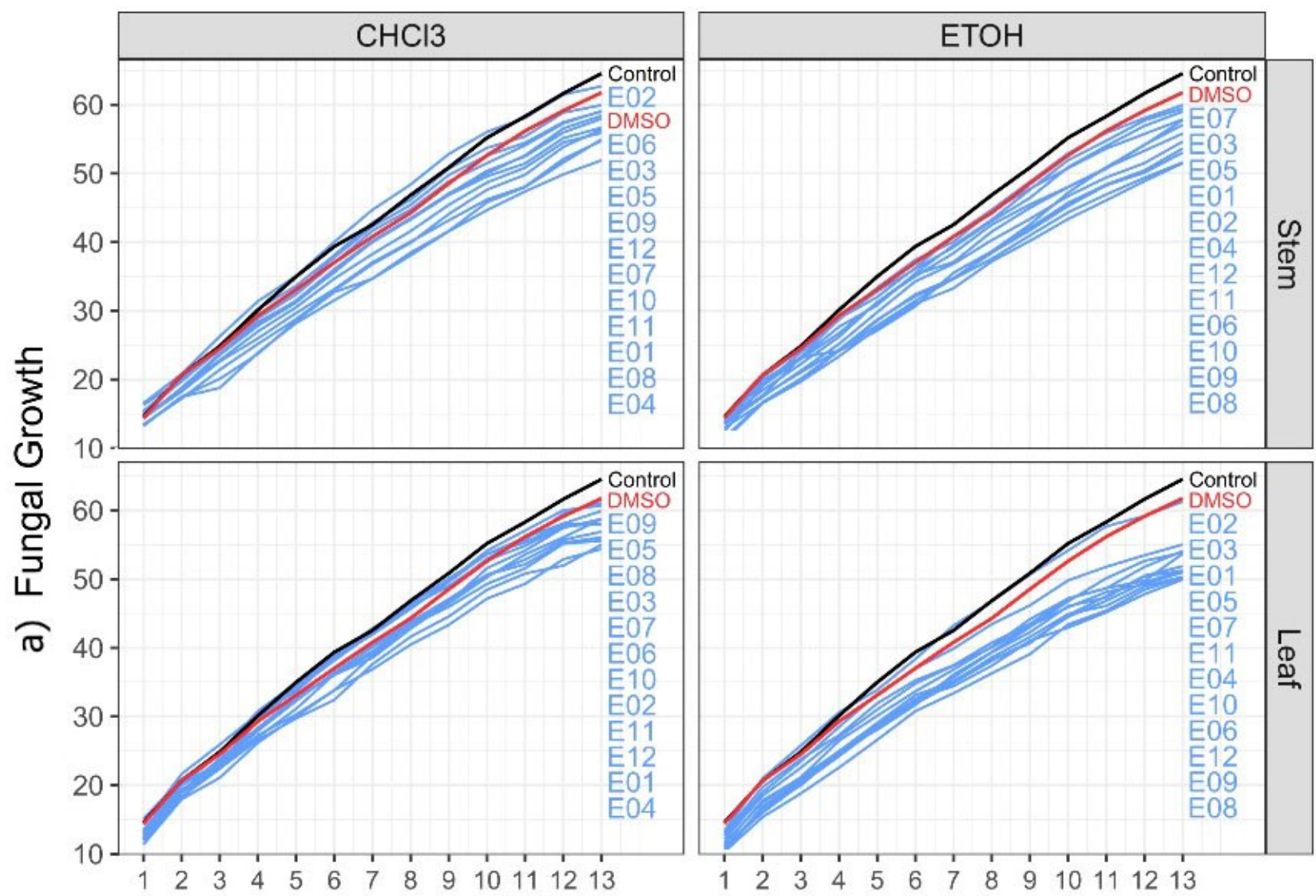

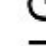
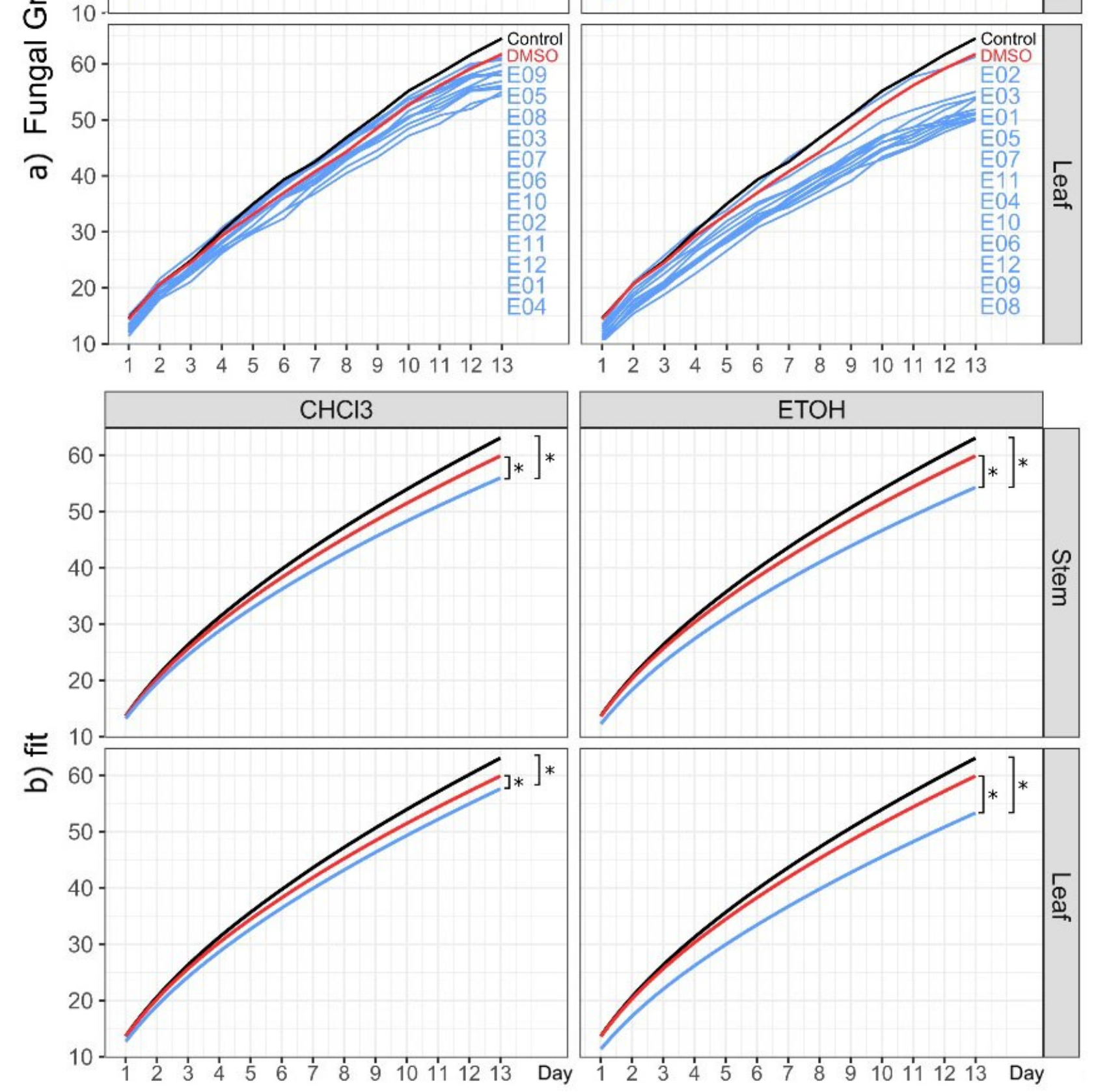

Treatment - Control - DMSO - Plant extract

Figure 2. Fungus Cercospora coffeicola growth over time (days). a) Mean values of the triplicates of each treatment [controls (Water and DMSO 2\%) and extracts (E)]. b) Stoffels' model fitting. 
From a statistical perspective, the regression model 4 represented the best fit to the data. In this case, the results it produced $\left(r=0.973 ; R^{2}=0.947\right.$, and $\mathrm{RMSE}=8.704$ ) were as good as those of the quadratic model, but without the concavity of the latter - which could have caused a misinterprettation of the fungal growth behavior (Table 1).

Figure 2a illustrates that all treatments had rising linear trends, but with some differences among them. It is interesting to note that the extracts E04 (treated with chloroform) and E08 (with ethanol), from both stem bark and leaves, showed the lowest mycelial growth rate. This outcome indicates that these extracts were the most toxic to the fungus. In Figure $2 b$, the curves corresponding to the extracts are compared to those of the two controls, evidencing the significant differences between them. The significance $p$ values obtained for the extracts and the controls (water and DMSO $2 \%$, in that order) were the following: $9.55 \mathrm{e}^{-10 * * *}$ and $2.79 \mathrm{e}^{-03 * *}$, for the chloroform extract of stem bark; $1.46 \mathrm{e}^{-21 * * *}$ and $2.25 \mathrm{e}^{-11 * * *}$, for the ethanol extracts of stem bark; $2.87 \mathrm{e}^{-12 * * *}$ and $1.71 \mathrm{e}^{-03 * *}$, for the chloroform extracts of leaves; and $4.69^{\mathrm{e}-41 * * *}$ and $6.55 \mathrm{e}^{-}$ $26 * * *$, for the ethanol extracts of leaves.

A two-way Anova (Table 2) revealed significant differences between the treatments. Nevertheless, no significant difference was found between the plant organs used. One factor that must be considered, though, is that the extracts that had ethanol as a solvent were more toxic than those using chloroform. This result is relevant because manufacturing the biocide via ethanol extraction is less expensive, and the solvent is more accessible to the farmers.

Table 1. Fitting of linear and linearized models to explain the relationship between the variable measure $(y$, in proper unit) versus time ( $x$, in days). The quality parameters of the models ( $r$ : correlation, $R^{2}$ : coefficient of determination, and RMSE: square root of error mean square) were obtained by using all data (neither families nor experimental components were discriminated).

\begin{tabular}{clccc}
\hline Model & Equation & $\boldsymbol{r}$ & $\boldsymbol{R}^{\mathbf{2}}$ & RMSE (\%) \\
\hline 1 & $y=\beta_{0}+\beta_{1} x+e$ & 0.970 & 0.941 & 9.079 \\
\hline 2 & $y=\beta_{0}+\beta_{1} x+\beta_{2} x^{2}+e$ & 0.974 & 0.949 & 8.452 \\
\hline 3 & $y=\beta_{0}+\beta_{1} \ln (x)+e$ & 0.943 & 0.889 & 12.452 \\
\hline 4 & $\ln (\boldsymbol{y})=\boldsymbol{\beta}_{\mathbf{0}}+\boldsymbol{\beta}_{\mathbf{1}} \ln (\boldsymbol{x})+\boldsymbol{e}$ & $\mathbf{0 . 9 7 3}$ & $\mathbf{0 . 9 4 7}$ & $\mathbf{8 . 7 0 4}$ \\
\hline 5 & $\ln (y)=\beta_{0}+\beta_{1} 1 / x+e$ & 0.883 & 0.780 & 18.961 \\
\hline
\end{tabular}

Table 2. Anova in split-split plot scheme considering Treatments [Controls (Water and DMSO) and Extracts]; Plant organ (Leaves, Stem bark); Solvent (Chloroform, Ethanol); and Days (1, 2, ..., 13).

\begin{tabular}{|c|c|c|c|c|c|c|}
\hline FV & df & SS & MS & $\mathbf{F}$ & $p$-value & \\
\hline Treatment & 2 & 4320 & 2159.8 & 79.388 & $1.20 \mathrm{e}-07$ & $* * *$ \\
\hline Plant organ & 1 & 19 & 19.5 & 0.716 & 0.4140 & \\
\hline Treatment $\times$ Plant organ & 2 & 3 & 1.6 & 0.06 & 0.9420 & \\
\hline Error a & 12 & 326 & 27.2 & & & \\
\hline Solvent & 1 & 2527.4 & 2527.4 & 890.33 & $1.26 \mathrm{e}-12$ & $* * *$ \\
\hline Treatment/Solvent & 2 & 421.2 & 210.6 & 74.19 & $1.75 e-07$ & $* * *$ \\
\hline Plant organ/Solvent & 1 & 387 & 387 & 136.31 & $6.56 e-08$ & $* * *$ \\
\hline$($ Treatment $\times$ Plant organ)/Solvent & 2 & 64.5 & 32.2 & 11.36 & 0.0017 & $* *$ \\
\hline Error b & 12 & 34.1 & 2.8 & & & \\
\hline Day & 12 & 408573 & 34048 & 5503.179 & $<2 \mathrm{e}-16$ & $* * *$ \\
\hline Solvent/Day & 12 & 260 & 22 & 3.501 & 3.77e-05 & $* * *$ \\
\hline Treatment/Day & 24 & 860 & 36 & 5.791 & $<2 \mathrm{e}-16$ & $* * *$ \\
\hline Plant organ/Day & 12 & 155 & 13 & 2.093 & 0.0147 & $*$ \\
\hline Treatment/Solvent/Day & 24 & 43 & 2 & 0.292 & 0.9997 & \\
\hline Plant organ/Solvent/Day & 12 & 131 & 11 & 1.76 & 0.0495 & $*$ \\
\hline Treatment $\times$ Plant organ/Day & 24 & 26 & 1 & 0.174 & 1.0000 & \\
\hline Treatment $\times$ Plant organ/Solvent/Day & 24 & 22 & 1 & 0.147 & 1.0000 & \\
\hline Error c & 2004 & 12399 & 6 & & & \\
\hline
\end{tabular}


The preparations using the $12 \mathrm{~J}$. curcas families reduced the growth of $C$. coffeicola by $11.22 \%$ and $10.47 \%$, considering the chloroform extracts of stem and leaves, respectively, and by $13.98 \%$ and $18.15 \%$, for the ethanolic extract of these parts (Table 3). Likewise, Silva et al. (2014) evaluated extracts of different plant species against this fungus, and reported a $64.48 \%$ decrease in mycelial growth when Allium sativum L., Vernonia polysphaera Baker, and Syzygium aromaticum Perry were employed. Chalfoun et al. (2009), in their turn, verified a diminution by $5.05 \%$ in $C$. coffeicola proliferation when $10 \mu \mathrm{L}$ of methanolic extract of Curcuma longa was applied.

Table 3. Percentage of mycelial growth inhibition (PMGI) of Cercospora coffeicola after apply the Jatropha curcas extracts.

\begin{tabular}{|c|c|c|c|c|}
\hline \multirow{3}{*}{ Families } & \multicolumn{4}{|c|}{ PMGI (\%) } \\
\hline & \multicolumn{2}{|c|}{ Chloroform extract } & \multicolumn{2}{|c|}{ Ethanolic extract } \\
\hline & Stem bark & Leaves & Stem bark & Leaves \\
\hline 5 & 8.57 & 5.93 & 8.57 & 16.53 \\
\hline 2 & 2.89 & 11.84 & 10.49 & 5.05 \\
\hline 3 & 8.47 & 8.93 & 7.90 & 14.72 \\
\hline 6 & 7.13 & 10.03 & 16.90 & 21.01 \\
\hline 7 & 12.21 & 8.95 & 14.88 & 16.80 \\
\hline 8 & 15.15 & 7.15 & 20.23 & 22.62 \\
\hline 9 & 9.53 & 5.29 & 20.05 & 22.17 \\
\hline 10 & 12.64 & 10.13 & 17.84 & 20.61 \\
\hline 11 & 13.40 & 13.12 & 15.36 & 19.59 \\
\hline 12 & 10.21 & 13.85 & 13.55 & 22.02 \\
\hline 1 & 14.87 & 14.73 & 10.34 & 16.20 \\
\hline 4 & 19.57 & 15.72 & 11.59 & 20.53 \\
\hline Mean & 11.22 & 10.47 & 13.98 & 18.15 \\
\hline CV (\%) & 39.02 & 32.77 & 30.47 & 27.03 \\
\hline
\end{tabular}

Ahirwar et al. (2015) studied the antifungal properties of both oil and extract of leaves of $J$. curcas. They made promising discoveries with the maximum zone of mycelial growth inhibition for Aspergillus niger. Even though other parts of the plant were not considered, all $J$. curcas organs possess toxicity. In order to test such effect, Ingle et al. (2017) utilized methanolic extracts of root, leaves, bark, and seeds to control phytopathogenic fungi. The crude root extract had the best antifungal activity against Rhizoctonia (up to $23.1 \%$ of growth inhibition).

When fractioned through a chromatography column, this preparation suppressed $72.72 \%$ and $41.17 \%$ of the proliferation of Fusarium udum and Rhizoctonia bataticola, respectively. These findings corroborate those obtained in the present study, since extracts of $J$. curcas limit the fungus growth, without eliminating it, however.

In our study, the ethanolic extract affected the development of both fungus species appraised. Actually, it attained the best toxicity results, which is interesting from the farmers' perspective, as its preparation is more feasible than the method with chloroform. This outcome concurs with the study conducted by Saetae and Suntornsuk (2010), who also assessed an ethanolic extract made from the seed cake of $J$. curcas. They detected an antifungal activity against major phytopathogens, such as Fusarium oxysporum, Pythium aphanidermatum, Lasiodiplodia theobromae, Curvularia lunata, $F$. semitectum, Colletotrichum capsica, and $C$. gloeosporiodes.

Thangavelu et al. (2004) made experimenttations with another type of solvent. They used an aqueous leaf extract of $J$. curcas in an attempt to control the etiologic agent of anthracnose (the fungus Colletotrichum musae) in banana and noticed inhibition of mycelial growth. Li et al. (2006) found similar results for Colletotrichum gloeosporiodes.

In literature, no reports were found approaching the antifungal effect of $J$. curcas extracts, specifically against $H$. vastatrix and C. coffeicola. This fact reaffirms the relevance of our study and stimulates further research on the isolation of molecules of interest from this plant. That way, it would be possible to discover green fungicides 
that can have their registration approved for coffee tree crops. In summary, all 12 extracts of stem bark and leaves of J. curcas, prepared with either ethanol or chloroform, proved to be efficient in controlling the fungus $H$. vastatrix, the cause of coffee leaf rust. In the tests with $C$. coffeicola, the extracts inhibited the mycelial growth, remarkably the ones identified as 04 and 08 (in all treatment combinations), which exhibited the lowest rates of fungal proliferation. These results allow the creation of a new line of research to select families of $J$. curcas with high content in bioactive compounds, aiming at the control of crop pathogens.

\section{Acknowledgments}

Thanks are due to CNPq, FAPEMIG and CAPES for financial support.

\section{References}

ABDELGADIR, H.A.; VAN STADEN, J. 2013. Ethnobotany, ethnopharmacology and toxicity of Jatropha curcas L. (Euphorbiaceae): A review. South African Journal of Botany, 88:204218. http://dx.doi.org/10.1016/j.sajb.2013.07.021

ABDUAL KHALIL, H.P.S.; SRI APRILIA, N.A.; BHAT, A.H.; JAWAID, M.; PARIDAH, M.T.; RUDI, D. 2013. A Jatropha biomass as renewable materials for biocomposites and its applications. Renewable and Sustainable Energy Reviews, 22:667-685. http://dx.doi.org/10.1016/j.rser.2012.12.036

AHIRWAR, R.K.; SAROJ, A.; PANDEYA, J.P.N.; MISHRA, A.S.; KUMAR, K.S. 2015. Antimicrobial activities of different plant extracts of Jatropha curcas Linn. Bulletin of Environmental and Scientifical Research, 4:21-28.

AKASHI, K. 2012. Jatropha research: a new frontier for biofuel development. Plant Biotechnology, 29:121. http://dx.doi.org/10.5511/plantbiotechnology.12.0003p.

AMORIM, L.; REZENDE, J.A.M.; CAMARGO, L.E.A. 2016. Manual de fitopatologia: doenças das plantas cultivadas. Agronômica Ceres, São Paulo, 810p.

CABI 2019. Invasive species compendium. Jatropha curcas (jatropha). Available at http://www.cabi.org/isc/datasheet/28393. Accessed on Nov 02, 2020.

CAETANO, A.R.S.; CARDOSO, M.G.; RESENDE, M.L.V.; ANGÉLICO, C.L.; CHALFOUN, S.M.; SILVA, J.A.G. 2017. Atividade antifúngica do óleo essencial de Eucalyptus microcorys sobre Hemileia vastatrix. In Anais do $43^{\circ}$ Congresso Brasileiro de Pesquisas Cafeeiras. SBICafé, Poços de Caldas, Minas Gerais.

CARDOSO, P.M.R.; DIAS, L.A.S.; RESENDE, M.D.V.; FREITAS, R.G.; CORREAA, T.R.; MUNIZ, D.R.; ZAIDAN, I.R. 2018. Genetic evaluation and selection in Jatropha curcas L.. Crop Breeding Applied Biotechnology, 18:192-199. http://dx.doi.org/10.1590/1984$\underline{70332018 \mathrm{v} 18 \mathrm{n} 2 \mathrm{a} 27}$

CARVAlHO, A.M.; CARDOSO, D.A.; CARVALHO, G.R.; CARVALHO, V.L.; PEREIRA, A.A.; FERREIRA, A.D.; CARNEIRO, L.F. 2017. Comportamento de cultivares de cafeeiro sob a incidência das doenças da ferrugem e cercosporiose em dois ambientes de cultivo. Coffee Science, 12:100-107. 
CAVALCANTE, N.B.; SANTOS, A.D.C.; ALMEIDA, J.R.G.S. 2020. The genus Jatropha (Euphorbiaceae): A review on secondary chemical metabolites and biological aspects. Chemico-Biological Interactions, 318:108976. http://dx.doi.org/10.1016/j.cbi.2020.108976

CHALFOUN, S.M.; OLIVEIRA, D.F.; SOUZA, L.P.; BOTELHO, D.M.S.; PEREIRA, M.C.; MACIEL, W.M.; CARVALHO, D.A. 2009. Seleção de extratos vegetais para controle da cercosporiose do cafeeiro. In Anais do VI Simpósio de Pesquisa dos Cafés do Brasil. SBICafé, Vitória, Espírito Santo.

DEVAPPA, R.K.; MAKKAR, H.P.S.; BECKER, K. 2010. Jatropha toxicity - a review. Journal of Toxicology and Environmental Health, Part B, 13:476-507. http://dx.doi.org/10.1080/10937404.2010.499736

DIAS, L.A.S.; BARROS, W.S. 2009. Biometria experimental. Suprema, Viçosa, 408p.

DIAS, L.A.S.; MISSIO, R.F.; DIAS, D.C.F.S. 2012. Antiquity, botany, origin and domestication of Jatropha curcas (Euphorbiaceae), a plant species with potential for biodiesel production. Genetics and Molecular Research, 11:2719-2728. http://dx.doi.org/10.4238/2012.June.25.6

DUARTE, D.; OLIVEIRA, M.; SANTANA, K.; IOST, R. 2018. Avaliação de germinação de esporos de Hemileia vastatrix utilizando extrato etanólico de folhas de Nim (Azadirachta indica). Summa Phytopathologica, 44:Supplement February.

FARIA, D.S.; UEBEL, J.; LEMOS, M.; J. FILHO, M. 2017. Eficiência de dois programas da Adama no controle das principais doenças do cafeeiro na região da Alta Mogiana. In Anais do $43^{\circ}$ Congresso Brasileiro de Pesquisas Cafeeiras. SBICafé, Poços de Caldas, Minas Gerais.

HORWITZ, W. (ed.) 1975. Official methods of analysis. Association of Official Analytical Chemists, $13^{\text {th }}$ edn, Washington, DC.

INGLE, K.P.; DESHMUKH, A.G.; PADOLE, D.A.; DUDHARE, M.S.; MOHARIL, M. P.; KHELURKAR, V. C. 2017. Screening of insecticidal activity of Jatropha curcas (L.) against diamond back moth and Helicoverpa armigera. Journal of Entomology and Zoology Studies, 5:44-50.

LI, H.-Y.; WANG, L.; ZHAO, Z.-W. 2006. Endophytic fungi of Jatropha curcas Linn. and their antifungal activity. National Product and Research Development, 18:78-80.

LI, H.; TSUCHIMOTO, S.; HARADA, K.; YAMASAKI, M.; SAKAI, H.; WADA, N.; ALIPOUR, A.; SASAI, T.; TSUNEKAWA, A.; TSUJIMOTO, H. ANDO, T.; TOMEMORI, H.; SATO, S.; HIRAKAWA, H.; QUINTERO, V.P.; ZAMARRIPA, A.; SANTOS, P.; HEGAZY, A.; ALI, A.M.; FUKUI, K. 2017. Genetic tracing of Jatropha curcas L. from its Mesoamerican origin to the world. Frontiers in Plant Science, 8:1539. http://dx.doi.org/10.3389/fpls.2017.01539

MUNIZ, D.R.; ZAIDAN, I.R.; DIAS, L.A.S.; LEITE, J.P.V.; DINIZ, J.A. 2020. Biocide potential of Jatropha curcas L. extracts. Journal of Biology and Life Science, 11:138-154. http://dx.doi.org/10.5296/jbls.v11i2.17341

OOTANI, M.A.; AGUIAR, R.W.; RAMOS, A.C.C.; BRITO, D.R.; SILVA, J.B.; CAJAZEIRA, J.P. 2013. Use of essential oils in agriculture. Journal of Biotechnology and Biodiversity, 4:162174. 
PANDEY, V.C.; SINGH, K.; SINGH, J.S.; KUMAR, A.; SINGH, B.; SINGH, R.P. 2012. Jatropha curcas: A potential biofuel plant for sustainable environmental development. Renewable and Sustainable Energy Reviews, 16:2870-2883. http://dx.doi.org/10.1016/j.rser.2012.02.004.

PUA, F.; FANG, Z.; ZAKARIA, S.; GUO, F.; CHIA, C. 2011. Direct production of biodiesel from high-acid value Jatropha oil with solid acid catalyst derived from lignin. Biotechnology for Biofuels, 4:56. http://dx.doi.org/10.1186/1754-6834-4-56.

SAETAE, D.; SUNTORNSUK, W. 2010. Antifungal activities of ethanolic extract from Jatropha curcas seed cake. Journal of Microbiology and Biotechnology, 20:319-324. http://dx.doi.org/10.4014/jmb.0905.05035

SILVA, A.C.A.; ABREU, G.F.; MACEDO, D.D.; RIBEIRO, D.E.; VOLTOLINI, G.B.; ALVES, G.; SILVA, A.D.; GUIRALDELI, C.H.C. 2015. Fitossanidade do cafeeiro: relação com a qualidade sensorial. In Anais do IX Simpósio de Pesquisa dos Cafés do Brasil, Curitiba, Paraná.

SILVA, C.L.; S FILHO, G.M.; PAIVA, R.N. 2016. Efeito das aplicações de fungicidas-inseticidas via solo com complementação foliar, para o controle de ferrugem do cafeeiro (Hemileia vastatrix). In Anais do $\mathbf{4 2}^{\circ}$ Congresso Brasileiro de Pesquisas Cafeeiras. SBICafé, Serra Negra, São Paulo.

SILVA, J.L.; SOUZA, P.E.; MONTEIRO, F.P.; FREITAS, M.L.O.; Silva Júnior, M.B.; Belan, L.L. 2014. Antifungal activity using medicinal plant extracts against pathogens of coffee tree. Revista Brasileira de Plantas Medicinais, 16:539-544. http://dx.doi.org/10.1590/1983$\underline{084 X / 12 \quad 155}$

THANGAVELU, R.; SUNDARARAJU, P.; SATHIAMOORTHY, S. 2004. Management of anthracnose disease of banana caused by Colletotrichum musae using plant extracts. The Journal of Horticultural Science and Biotechnology, 79:664-668. http://dx.doi.org/10.1080/14620316.2004.11511823

WEI, Q.; LIAO, Y.; ZHOU, L.J.; ZHOU, J.X.; WANG, S.H.; CHEN, F. 2004. Antifungal activity of curcin from Jatropha curcas seeds. Chinese Journal of Oil Crop Science, 26:71-75.

ZAMBOLIM, L. 1999. I Encontro sobre produção de café com qualidade. UFV, Viçosa, 259p. 